\title{
TINJAUAN FIQH MUAMALAH TERHADAP PRAKTIK KERJASAMA BANK SAMPAH DI DESA CANDIMULYO KEC. DOLOPO KAB. MADIUN
}

\author{
Roisul Malik \\ Institut Agama Islam Negeri (IAIN) Ponorogo \\ Roisulmalik94@gmail.com
}

\begin{abstract}
Abstrak
In general, a bank is a place where we can do various kinds of transactions such as withdrawal, borrowing, and depositing money. But the object used as a transaction tool here is not something as valuable as money, but garbage. So, people who want to become customers of this bank do not need to have assets or something that is valuable (either money or other valuables), simply by owning trash, then they can become customers. In Islam, this form of cooperation is one form of cooperation in the economic field that is a form of giving assets from one person to another as venture capital where the profits obtained will be divided between the two of them in accordance with the agreement. The purpose of this study was to examine the muamalat contract which was applied by a garbage bank in Madiun Regency. Factual information obtained from Bank Sampah "Srikandi" of Candimulyo Village is related to the practice of saving related to the contract and profit sharing implemented by the manager of the garbage bank. By using Muamalah Fiqh in conducting research, then evaluating with various theories relating to the main problem in this research, obtained research results: there are waste bank products such as savings systems, profit sharing cooperation, and various transactions that are in accordance with all contracts. Based on these factors then garbage bank becomes halal for transactions and is eligible to become one of the Islamic Financial Institutions.
\end{abstract}

Keywords: Cooperation, Revenue Sharing, Garbage Bank

Pada prinsipnya bank adalah sebuah tempat dimana kita bisa melakukan berbagai macam transaksi seperti penarikan, peminjaman, dan penyimapanan uang. Namun di sini objek yang digunakan sebagai alat transaksi bukanlah sesuatu yang berharga tetapi sampah. Jadi barang siapa yang ingin menjadi nasabah bank sampah ini tidak perlu memiliki harta atau sesuatu yang berharga (baik uang atau barang berharga lainnya) namun siapapun yang memiliki sampah boleh menjadi nasabah. Di dalam Islam bentuk kerjasama tersebut merupakan salah satu bentuk kerjasama dalam lapangan ekonomi yaitu bentuk pemberian harta dari seseorang pada orang lain sebagai modal usaha di mana keuntungan yang diperoleh akan dibagi di antara mereka berdua sesuai dengan kesepakatan. Tujuan dari penelitian ini adalah untuk meneliti akad muamalat yang diaplikasikan oleh salah satu Bank Sampah yang ada di daerah Madiun karena Bank Sampah ini merupakan Bank Sampah yang baru berdiri tapi sudah sering mendapat penghargaan dari pemerintah Madiun. Penelitian ini menggunakan pendekatan Fiqh Muamalah (figh oriented) dengan jenis penelitian lapangan. Informasi faktual yang diperoleh dari Bank Sampah "Srikandi" Desa Candimulyo terkait dengan praktek tabungan sampah terkait akad dan pembagian keuntungan yang diterapkan oleh pengelola Bank Sampah dalam hal ini peneliti menggunakan Fiqh Muamalah dalam melakukan penelitian yang kemudian mengevaluasi dengan berbagai teori yang berkaitan dengan pokok masalah dalam penelitian ini. Hasil dari penelitian ini adalah, terdapat produk-produk bank sampah seperti sistem tabungan, kerja sama bagi hasil, dan berbagai transaksi yang sesuai dengan akad mua'malah. Faktor-faktor inilah yang membuat bank sampah menjadi halal untuk ditransaksikan dan layak menjadi salah satu Lembaga Keuangan Syariah.

Kata kunci: Kerjasama, Bagi Hasil, Bank Sampah 


\section{Pendahuluan}

Permasalahan lingkungan yang sekarang terjadi salah satunya adalah permasalahan sampah, yang kian hari terus menumpuk jumlahnya. Pemegang kebijakan yaitu pemerintah sudah menangani permasalahan ini yaitu mengolah sampah secara terpadu, misalnya dari sampah rumah tangga. Sampah sering kali hanya dibuang begitu saja ke tempat pembuangan sampah. Menumpuk tinggi hingga akhirnya diangkut oleh petugas kebersihan tanpa tahu kemana akan bermuara. Tak sempat sampah itu dipilah antara yang organik maupun yang anorganik. Bahkan jarang pula yang terpikir jika sebenarnya sampah itu bisa ditabung. ${ }^{1}$ Menurut Hadiwiyoto jika ditinjau dari segi keseimbangan lingkungan, kesehatan, keamanan dan pencemaran, apabila sampah tidak dikelola dengan baik dapat menimbulkan berbagai gangguan-gangguan antara lain pencemaran udara, pencemaran air dan pencemaran tanah. ${ }^{2}$

Allah menjadikan manusia dengan saling membutuhkan satu sama lain, supaya mereka saling menolong, tukar menukar keperluan dalam segala hal urusan yang menyangkut kepentingan hidup masing-masing, baik dengan jalan jual beli, sewa menyewa, kerjasama, atau perusahaan dan lain-lain, baik dalam urusan kepentingan sendiri maupun untuk kemaslahatan umum. Dengan cara demikian kehidupan masyarakat menjadi teratur, pertalian antara yang satu dengan yang lain menjadi baik. Sistem perilaku tersebut dalam Islam disebut dengan istilah muamalah. ${ }^{3}$ Sesuai deskripsi di atas, yang dimaksud dengan muamalah dalam perspektif Islam adalah tukar menukar barang atau sesuatu yang memberi manfaat dengan cara yang ditentukan seperti jual beli, sewa menyewa, upah mengupah, pinjam-meminjam berserikat dan usaha-usaha lainnya. ${ }^{4}$

Manusia diciptakan oleh Allah SWT sebagai seorang khalifah dan sebagai seorang khalifah yang baik hendaknya memiliki sikap kearifan dan kemampuan yang tinggi untuk mengelola bumi dan isinya, termasuk yang ada di dalamnya yaitu menjaga sumber daya air dan juga tidak membuang sampah sembarangan agar untuk menjaga dan memeliharanya agar tetap asri. Lingkungan yang asri akan mendatangkan manfaat bagi umat manusia di bumi. Tumbuhtumbuhan, ternak, dan segala ciptaan Tuhan akan berkembang dengan baik, di lingkungan yang

\footnotetext{
${ }^{1}$ Ade Yulia, Memotret Bank Sampah PAS Arcawinangun, (http://ajikotapurwokerto.or.id/ 2013/04/10/memotret-bank-sampah-pas-arcawinangun), diakses pada tanggal 7 September 2018, pukul 22.47.

${ }^{2}$ Bambang Rustanto, "Bank Sampah" (http://bambang rustanto.blogspot.com /2013/08/bank sampah.html), di akses pada tanggal 7 september 2018, pukul 22.51.

${ }^{3}$ M. Abdul Manan, Islamic Economics Theory and Practice, Terj. Nastangin “ Teori dan praktek ekonomi Islam”. Yogjakarta: PT. Dana Bhakti Wakaf,1997, 27

${ }^{4}$ Sulaiman Rasjid, Fiqh Islam, Bandung : PT. Sinar Baru Algensindo, 1998, Cet. Ke-32, 278
} 
asri guna kepentingan manusia. Sayangnya lingkungan yang asri sudah banyak yang rusak oleh tangan-tangan yang tidak bertanggung jawab, sehingga bencana terjadin di mana-mana. Dalam konsep Islam barang yang sudah tidak digunakan (sampah rumah tangga) limbah atau sampah adalah berbagai benda padat atau cair yang terbuang dari hasil kegiatan manusia atau alam dan dianggap tidak berguna.

Islam adalah Din yang di dalamnya termuat berbagai metode solving prolem yang mengakar kuat kepada akidahnya. Segala persoalan dan penyelesaiannya berdasarkan kepada akidah Islam. Kebersihan dan kesucian adalah salah satu syariat Islam, mencintai sesama dan mencintai lingkungan adalah cabang dari beberapa bagian aturannya. ${ }^{5}$

Namun masyarakat memandang bahwa sampah adalah sesuatu yang kotor, jorok, dan menjijikkan juga kurangnya kesadaran masyarakat dalam menjaga lingkungan serta langkanya bank sampah. Padahal Islam mengajarkan menjaga alam dan lingkungan termasuk menanggulangi sampah dengan mengelola sampah tersebut. Sebagaimana Firman Allah SWT dalam Q.S Al-A'raf ayat 56

Artinya: "Dan janganlah kamu membuat kerusakan di muka bumi, sesudah (Allah) memperbaikinya dan berdoalah kepada-Nya dengan rasa takut (tidak akan diterima) dan harapan (akan dikabulkan). Sesungguhnya rahmat Allah amat dekat dengan orang-orang yang berbuat baik. ${ }^{6, "}$

Dalam ayat tersebut di atas dijelaskan bahwa Allah, melarang umat manusia untuk membuat kerusakan di muka bumi. Allah mengirim manusia sebagai khalifah yang seharusnya mampu memanfaatkan, mengelola dan memelihara bumi dengan baik bukan malah sebaliknya. Keserakahan sebagian manusia terhadap alam dapat menyengsarakan manusia itu sendiri. Banjir, pencemaran lingkungan yang tidak nyaman karena sampah merupakan buah dari kelakuan manusia yang tidak dapat menjaga lingkungan dan justru merugikan manusia itu sendiri dan makhluk lainnya.

Salah satu terobosan besar dalam pengelolaan sampah di Indonesia adalah program bank sampah. Melalui program ini, paradigma yang terbentuk dalam pikiran masyarakat bahwa sampah adalah sesuatu yang tidak berguna dan dibuang begitu saja, diubah menjadi sesuatu

\footnotetext{
${ }^{5}$ Mohammad Elmeidian, Perspektive Islam Dalam Management Sampah Atau Limbah, http://fokalink.blogspot.com/2011/06/perspektive-islam-dalam-management.html ( di akses pada tanggal 7 September 2018 pukul 22.57).

${ }^{6}$ Al-Qur'an Terjemah, Karya Agung : Surabaya 2014, 157.
} 
yang juga memiliki nilai dan harga. Melalui bank sampah, masyarakat bisa menabung sampah, yang kemudian dalam kurun waktu tertentu bisa menghasilkan uang.

Pada prinsipnya bank adalah sebuah tempat dimana kita bisa melakukan berbagai macam transaksi seperti penarikan, peminjaman dan penyimapanan uang, Namun di sini objek yang digunakan sebagai alat transaksi bukanlah sesuatu yang berharga tetapi sampah. Jadi barang siapa yang ingin menjadi nasabah bank sampah ini tidak perlu memiliki harta atau sesuatu yang berharga (baik uang atau barang berharga lainnya) namun siapapun yang memiliki sampah boleh menjadi nasabah.

Di masyarakat praktik kerjasama antara pihak satu dengan yang lain sering dilakukan yaitu kerja sama dengan bagi hasil. Namun pada umumnya di Indonesia hukum adat atau kebiasaan setiap daerah memiliki istilah berbeda-beda.

Di dalam Islam bentuk kerja sama tersebut merupakan salah satu bentuk kerjasama dalam lapangan ekonomi yaitu bentuk pemberian harta dari seseorang pada orang lain sebagai modal usaha dimana keuntungan yang diperoleh akan dibagi diantara mereka berdua sesuai dengan kesepakatan. Dalam hukum Islam, praktek kerjasama bagi hasil seperti ini termasuk dalam kategori Mud̄ārabah. Keduanya mempunyai kesepakatan untuk kerjasama, kemudian hasilnya akan dibagi sesuai dengan kesepakatan.

Di bank sampah yang ada di Desa Candimulyo terdapat kerjasama dalam penyimpanan sampah dengan menggunakan bagi hasil antara nasabah dengan pengelola bank sampah. Sampah yang dibawa nasabah ke Bank Sampah ini dipilah oleh pengelola Bank. Ada yang dijual ke pengepul, ada yang dibuat kerajinan daur ulang, dan ada yang dibuat kompos. Uang dari penjualan sampah tersebut kemudian disimpan di Bank Sampah dan dikelola oleh Bank Sampah. Dari pengelolaan uang sampah tersebut ada semacam bagi hasil antara Bank Sampah dengan nasabah. Persentase bagi hasil tersebut adalah 65\% untuk nasabah dan $35 \%$ untuk pengelola Bank Sampah dan perjanjian ini disepakati diawal warga mendaftar sebagai nasabah baru di Bank Sampah. Namun dalam praktiknya kesepakatan ini kadang-kadang tidak berjalan semestinya, karena ada situasi yang mengakibatkan ini tidak berjalan, yaitu ketika harga jual sampah menurun sedangkan pasokan sampah menumpuk. Pembagian keuntungan ini harusdi kurangi dari salah satu pihak saja yaitu dari pengelola Bank Sampah sehingga ini dianggap merugikan bagi masyarakat pengepul sampah. Dari penjualan sampah ini tidak langsung diberikan kepada masyarakat pengumpul sampah tapi ditabung dulu sampai si pengumpul sampah tersebut membutuhkan. Dan hasil dari tabungan ini tidak hanya berupa uang saja tapi bisa dimintai untuk membayar listrik, PDAM, dan lain sebagainya. 
Berdasarkan latar belakang di atas perlu diadakan penelitian lebih lanjut tentang akad yang diaplikasikan oleh salah satu bank sampah yang ada di desa Candimulyo ini serta kesesuaiannya dengan ketentuan hukum Islam.

\section{Metode Penelitian}

Penelitian ini menggunakan pendekatan Fiqh Muamalah (fiqh oriented). Metode ini merupakan penelitian yang pemecahan masalahnya disandarkan pada pendapat para Imam Mujtahid berdasarkan dalil syar'I atas permasalahan yang terjadi. Metode ini dipilih untuk mendapat solusi

terbaik sesuai Syari'at Islam. Jenis penelitian yang digunakan dalam penelitian ini adalah penelitian lapangan (field research). Penelitian lapangan merupakan suatu penelitian yang dilakukan dalam kancah kehidupan sebenarnya. Penelitian lapangan pada hakekatnya merupakan metode untuk menemukan secara khusus dan realistik apa yang tengah terjadi pada suatu saat di tengah masyarakat. ${ }^{7}$

\section{A. Mudarabah menurut Fiqh Muamalah}

1. Pengertian Mudarabah

Kata Mudarabah secara etimologi berasal dari kata $d$ farb. Dalam bahasa Arab, kata ini termasuk diantara kata yang mempunyai banyak arti. Di antaranya memukul, berdetak, mengalir, berenang, bergabung, menghindar berubah, mencampur, berjalan, dan lain sebagainya. Perubahan makna tersebut bergantung pada kata yang mengikutinya dan konteks yang membentuknya.

Secara terminologis, $m u d\} a>$ rabah diungkap secara bermacam-macam oleh para ulama madhhab. Di antaranya menurut madhhab H janafi>, "suatu perjanjian untuk berkongsi di dalam keuntungan dengan modal dari salah satu pihak dan kerja (usaha) dari pihak lain."Sedangkan madhhab Maliki mendefinisikan sebagai penyerahan uang dimuka oleh pemilik modal dalam jumlah uang yang ditentukan kepada seseorang yang akan menjalankan usaha dengan uang tersebut dan imbalan sebagian dari keuntungannya. ${ }^{8}$

madhhab Shafi' $i>$ mendefinisikan bahwa pemilik modal menyerahkan sejumlah uang kepada pengusaha untuk dijalankan dalam suatu usaha dengan keuntungan menjadi milik bersama antara keduanya. Sedangkan madhhab Hambali menyatakan

\footnotetext{
${ }^{7}$ Aji Damanuri, Metodologi Penelitian Mu'amalah (Ponorogo: STAIN Ponorogo Press, 2010), 6.

${ }^{8}$ Naf'an, Pembiayaan Musya > rakah dan Mud) $a>$ rabah (Yogyakarta: Graha Ilmu, 2014), 113.
} 
sebagai penyerahan suatu barang atau sejenisnya dalam jumlah yang jelas dan tertentu kepada orang yang mengusahakannya dengan mendapatkan bagian tertentu dari keuntungannya.

Mud $\{a>$ rabah adalah akad antar pihak pemilik modal $(s\} a>h$ \}ibul $m a>l)$ dengan pengelola $($ mud $\} a>r i b)$ untuk memperoleh pendapatan atau keuntungan. Pendapatan atau keuntungan tersebut dibagi berdasarkan nisbah yang telah disepakati diawal akad. ${ }^{9}$

Menurut Khotibul Umam, $m u d\} a>r a b a h$ adalah penanaman dana dari pemilik dana $(s\} a>h$ \}ibul $m a>l)$ kepada pengelola dana $(m u d\} a>r i b)$ untuk melakukan kegiatan usaha tertentu, dengan pembagian menggunakan metode bagi untung dan rugi (profit and loss sharing) atau metode bagi pendapatan (revenuesharing) antara kedua belah pihak berdasarkan nisbah yang telah disepakati sebelumnya. ${ }^{10}$

Afzalur Rahman mendefinisikan $m u d$ ) $a>$ rabah sebagai bentuk kontrak kerja sama yang didasarkan pada prinsip profit sharing, yang satu sebagai pemilik modal dan yang kedua menjalankan usaha. Modal di sini berupa uang dan tidak boleh berbentuk barang. Pemilik modal dapat disebut $s\{a>h\}$ ibul $m a>l$, rabbul ma>l, atau propretior. Pengelola modal disebut mud $\} a>r i b$. Modal yang digulirkan disebut $r a$ 'sul $m a>l .{ }^{11}$

\section{B. Rukun dan Syarat Mudarabah}

Sebagaimana akad lain dalam syariat Islam, akad mud\}a $>$ rabah menjadi sah, maka harus memenuhi rukun dan syarat mud\}a>rabah. Menurut madhhab H>>> lanafi>, apabila rukun sudah terpenuhi tetapi syarat tidak terpenuhi maka rukun menjadi tidak lengkap sehingga akad tersebut menjadi fasid (rusak).

1. Rukun Mud\}a $>$ rabah

Rukun mud\}a>rabah adalah hal-hal yang harus dipenuhi untuk dapat terlaksananya akad mud\}a>rabah. Menurut jumhur ulama, ada tiga rukun mud $)$ > rabah antara lain:

a. Dua orang yang berakad yaitu pengelola modal (mud\}a>rib) dan orang yang mempunyai modal $(s\} a>h\}$ ibul $m a>l)$.

b. Materi yang diperjanjikan atau objek yang diakadkan terdiri atas modal $(m a>l)$, kerja, keuntungan.

c. Shighat yakni serah (ijab) dan terima (qabul).

${ }^{9}$ Ibid., 114.

${ }^{10}$ Khotibul Umam, Perbanan Syariah: Dasar-dasar dan Dinamika Perkembangannya di Indonesia (Jakarta: Rajawali Pres, 2016), 131.

${ }^{11}$ Ahmad Dahlan, Bank Syariah: Teoritik praktik Kritik (Yogyakarta: Teras, 2012), 129. 
Sedangkan menurut madhhab H\{anafiyyah, rukun $m u d\} a>$ rabah hanya satu ijab (ungkapan penyerahan modal) dan qabul (ungkapan menerima modal dan ungkapan persetujuan kedua belah pihak). ${ }^{12}$

Dari beberapa rumusan rukun $m u d\} a>$ rabah menurut para ulama di atas, dapat dipahami bahwa pada dasarnya rukun dalam akad mud\}a>rabah sesuai ketentuan syariah adalah:

1) Pelaku

a) Pelaku harus cakap hukum dan baligh.

b) Pelaku akad mud\}a $>$ rabah dapat dilakukan sesama atau non muslim.

c) Pemilik dana tidak boleh ikut campur dalam pengelolaan usaha tetapi ia boleh mengawasi.

2. Objek Mud\}a>rabah

Objek Mudfa>rabah meliputi modal yang merupakan konsekuensi logis dilakukannya akad mud\}a>rabah.

a) Modal

(1) Modal yang diserahkan dapat berbentuk uang tunai atau aset lainnya (dinilai sebesar nilai wajar), harus jelas jumlah dan jenisnya serta tidak utang.

(2) Pengelola dana tidak boleh memud\} $a>$ rabahkan kembali modal mud\} $a>$ rabah dan apabila terjadi maka dianggap pelanggaran kecuali atas seizin pemilik dana.

(3) Pengelola dana tidak diperbolehkan untuk meminjamkan modal kepada orang lain apabila terjadi maka dianggap pelanggaran kecuali atas seizin pemilik dana.

(4) Pengelola dana memiliki kebebasan untuk mengatur modal menurut kebijaksanaan dan pemikirannya sendiri, selama tidak dilarang secara syariah.

b) Kerja

Kontribusi pengelola dana dapat berbentuk keahlian, keterampilan, management skill, selling skill, dan lain-lain.

3. Ijab dan Kabul

Merupakan pernyataan dan ekspresi saling rid\} $a$ atau rela diantara pihak-pihak pelaku akad yang dilakukan secara verbal, tertulis, melalui korespondensi atau menggunakan cara-cara komunikasi modern. Dalam hal ini, kedua belah pihak harus secara rela bersepakat untuk mengikatkan diri dalam akad mud\}a>rabah. 2009), 75 .

${ }^{12}$ Adrian Sutedi, Perbankan Syariah Tinjauan dan Beberapa Segi Hukum, (Bogor: Ghalia Indonesia, 
4. Nisbah Keuntungan

Nisbah adalah besaran yang digunakan untuk pembagian keuntungan, mencerminkan imbalan yang berhak diterima oleh kedua pihak yang bermud\} $a>$ rabah atas keuntungan yang diperoleh. Nisbah keuntungan harus diketahui dengan jelas oleh kedua pihak, inilah yang akan mencegah terjadinya perselisihan antara keduapihak. Apabila terjadi perubahan nisbah maka harus berdasarkan kesepakatan kedua belah pihak. $^{13}$

\section{a. Syarat Mud\}a $>$ rabah}

Syarat $m u d\} a>$ rabah adalah hal-hal yang harus dipenuhi setelah rukunrukun di atas dapat terpenuhi. Menurut Sayyid Sabiq dalam suatu akad mud\}a > rabah harus memenuhi syarat sebagai berikut:

a. Bahwa modal itu berbentuk uang tunai, jika ia berbentuk emas atau perak batangan, atau barang dagangan atau perhiasan, maka tidak sah.

b. Bahwa ia diketahui dengan jelas, agar dapat dibedakannya modal yang diperdagangkan dengan keuntungan yang dibagikan untuk kedua belah pihak, sesuai dengan kesepakatan.

c. Bahwa keuntungan yang menjadi milik pekerja dan pemilik modal jelas prosentasenya.

d. Bahwa mudfa>rabah itu bersifat mutlak, pemilik modal tidak mengikat si pelaksana (pekerja) untuk berdagang di negeri tertentu dan juga waktu tertentu. $^{14}$

Menurut Daeng Naja dalam bukunya yang berjudul Akad Bank Syariah, menerangkan bahwa syarat-syarat mud $\}$ > rabah meliputi:

1) Modal harus diserahkan kepada muda>rib untuk memungkinkannya melakukan usaha.

2) Modal harus dalam bentuk tunai dan bukan piutang.

3) Modal harus dinyatakan dengan jelas mengenai jumlahnya, seandainya modal berbentuk barang maka barang tersebut harus dihargakan dengan harga sesama dalam uang yang beredar atau sejenisnya.

4) Pembagian keuntungan harus dinyatakan dalam persentase dari keuntungan yang mungkin dihasilkan nanti.

\footnotetext{
${ }^{13}$ Sri Nurhayati dkk, Akuntansi Syariah di Indonesia (Jakarta: Salemba Empat, 2011), 124.

${ }^{14}$ Abdul Ghofur Anshori, Hukum Perjanjian Islam di Indonesia (Yogyakarta: Gadjah Mada University Press, 2010), 104.
} 
5) Kesepakatan rasio persentase harus dicapai melalui negosiasi dan dituangkan dalam kontrak.

6) Pembagian keuntungan barudapat dilakukan setelah muda>rib mengembalikan seluruh atau sebagian modal kepada $s$ \}ah\}ibulma $>l .^{15}$

Apabila rukun dan syarat $m u d\} a>r a b a h$ telah terpenuhi, maka perjanjian tersebut akan mempunyai kekuatan hukum mengikat dan harus dilaksanakan dengan itikad baik oleh para pihak.

\section{Prinsip-Prinsip Mu\}arabah}

Berikut ini adalah prinsip-prinsip mud $\} a>$ rabah :

a. Prinsip Berbagi Keuntungan di Antara Pihak-pihak yang Melakukan Akad Mud\}a $>$ rabah

Dalam akad mud $\} a>r a b a h$, laba bersih harus dibagi antara $s\} a h\}$ ibul $m a>l$ dan mud $a>$ rib berdasarkan suatu proporsi yang adil sebagaimana telah disepakati sebelumnya dan secara eksplisit telah disebutkan dalam perjanjian mudfa>rabah. Pembagian yang ada tidak boleh dilakukan sebelum kerugian yang ada ditutupi dan ekuitas $s\} a>h$ libul $m a>l$ sepenuhnya dikembalikan. Semua kerugian yang terjadi dalam perjalanan bisnis harus ditutupi dengan laba sebelum hal itu ditutupi dengan ekuitas $s\} a>h$ libul $m a>l .{ }^{16}$

Adapun kerugian bersih harus ditanggung $s\} a>h\} i b u l m a>l$, sementara bentuk kerugian $m u d$ \}a $>$ rib adalah hilangnya waktu, tenaga, dan usahanya. Jika disepakati, bahwa keseluruhan laba akan dinikmati $m u d\} a>r i b$ atau modal yang diberikan harus dikembalikan secara utuh. Dalam hal ini, $s\} a>h\}$ ibul $m a>l$ dipandang sebagai pemberi pinjaman sehingga $m u d\} a>r i b$ dituntut untuk menanggung risiko dan mengembalikan modal.

Mud $\{$ a rabah merupakan perjanjian kerja sama yang didasari oleh tujuan mencari keuntungan. Oleh karena itu, keuntungan menjadi hak pihak-pihak yang melakukan akad mud\}a>rabah sesuai dengan proporsi yang sudah disepakati. Dasar akad ini adalah ta'awwun (tolong-menolong). Jika terjadi kerugian, pihak peminjam tetap harus mengembalikan harta tersebut kepada pemberi pinjaman. ${ }^{17}$

\section{Manfaat Mud\}a>rabah}

a. Manfaat Mud\}a $>$ rabah

\footnotetext{
${ }^{15}$ Daeng Naja, Akad Bank Syariah (Yogyakarta: Pustaka Yustisia, 2011), 52.

${ }^{16}$ Neneng Nurhasanah, Mud $) a>$ rabah dalam Teori dan Praktik (Bandung: Anggota IKAPI, 2015), 78.

${ }^{17}$ Ibid., 79.
} 
1) Bank akan menikmati peningkatan bagi hasil pada saat keuntungan usaha nasabah meningkat.

2) Bank tidak berkewajiban membayar bagi hasil kepada nasabah pendanaan secara tetap, tetapi disesuaikan dengan pendapatan/hasil usaha bank sehingga bank tidak akan pernah mengalami negative spread.

3) Pengembalian pokok pembiayaan disesuaikan dengan cash flow atau arus kas usaha nasabah sehingga tidak memberatkan nasabah.

4) Bank akan lebih selektif dan hati-hati mencari usaha yang benar-benar halal, aman, dan menguntungkan karena keuntungan yang konkret dan benar-benar terjadi itulah yang akan dibagikan.

5) Prinsip bagi hasil dalam $m u d\} a>$ rabah berbeda dengan prinsip bunga tetap, di mana bank akan menagih penerima pembiayaan (nasabah) satu jumlah bunga tetap berapapun keuntungan yang dihasilkan nasabah, sekalipun merugi dan terjadi krisis ekonomi.

\section{b. Risiko Mud\}a>rabah}

Risiko yang terdapat dalam mud\}a>rabah, terutama pada penerapannya dalam pembiayaan, relatif tinggi. Diantaranya:

1) Side streaming, nasabah menggunakan dana itu bukan seperti yang disebut dalam kontrak

2) Lalai dan kesalahan yang disengaja

3) Penyembunyian keuntungan oleh nasabah bila nasabahnya tidak jujur Berikut ini adalah skema Mud $\} a>$ rabah: ${ }^{18}$

Skema al- Mudharabah

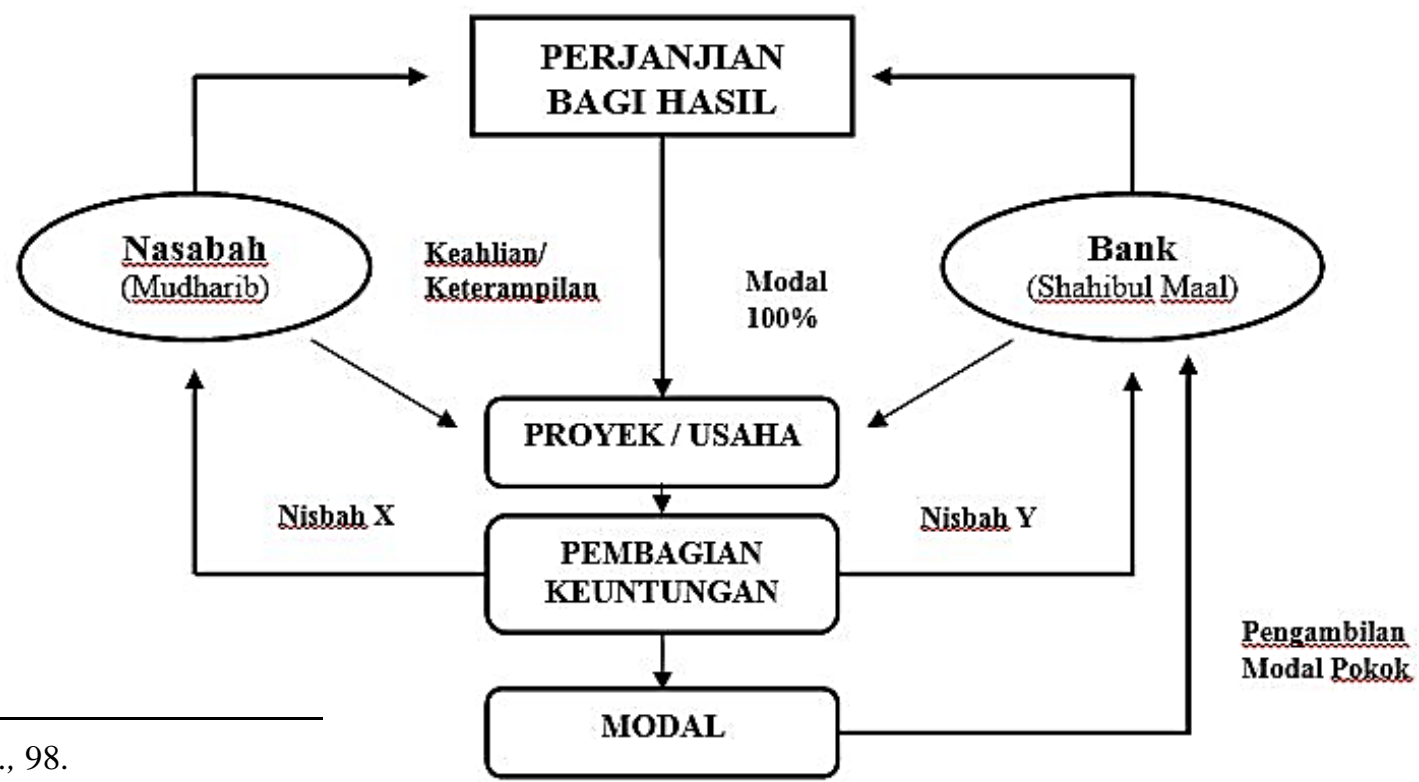

${ }^{18}$ Ibid., 98. 


\section{Keterangan:}

1) Nasabah mengajukan pembiayaan kepada bank atas suatu rencana proyek usaha. Kemudian diadakan negosiasi sampai bank menyetujui proyeksi yang diajukan oleh nasabah dengan syarat dan analisis yang ditetapkan oleh pihak bank. Pada tahap negosiasi tercapai kesepakatan berarti sudah terjadi asas konsensualisme.

2) Perjanjian dibuat dengan perlengkapan seluruh dokumen yang dibutuhkan. Pada tahap ini data diartikan sebagai asas formalisme. Di mana akad terjadi jika sudah terjadi formalitas suatu perjanjian sesuai dengan peraturan yang berlaku, bank sebagai $s$ \} $a>h$ libul $m a>l$ (pihak pertama), dan nasabah sebagai $m u d\} a>r i b$ (pihak kedua).

3) Nasabah menyalurkan dana pembiayaan untuk proyek yang telah disepakati.

4) Nasabah memberikan nisbah bagi hasil atau nilai keuntungan sesuai dengan nilai kontrak. Lazimnya dibayarkan secara regular dalam interval per-bulan

5) Perjanjian pembiayaan akad $m u d\} a>r a b a h$ selasai sesuai dengan nota perjanjian atau sebagian pihak mengakhiri dengan beberapa alasan peraturan atau perundangundangan yang berlaku.

\section{E. Hal-Hal Yang Membatalkan Akad Mu\}arabah}

Mud $a>$ rabah menjadi batal apabila ada perkara-perkara sebagai berikut:

a. Tidak terpenuhinya salah satu atau beberapa syarat $m u d\} a>$ rabah. Jika salah satu syarat mud $a>$ rabah tidak terpenuhi, sedangkan modal sudah dipegang oleh pengelola dan sudah diperdagangkan, maka pengelola mendapatkan sebagian keuntungannya sebagai upah, karena tindakan atas izin pemilik modal dan ia melakukan tugas berhak menerima upah. Jika terdapat keuntungan, maka keuntungan tersebut untuk pemilik modal. Jika ada kerugian, kerugian itu menjadi tanggung jawab pemilik modal karena pengelola adalah sebagai buruh yang hanya berhak menerima upah dan tidak bertanggung jawab sesuatu apa pun, kecuali atas kelalaiannya.

b. Pengelola dengan sengaja meninggalkan tugasnya sebagai pengelola modal atau pengelola modal berbuat sesuatu yang bertentangan dengan tujuan akad. Dalam keadaan 
seperti ini pengelola modal bertanggung jawab jika terjadi kerugian karena dialah penyebab kerugian.

c. Apabila pelaksana atau pemilik modal meninggal dunia, mud $\} a>$ rabah menjadi batal. ${ }^{19}$

d. Salah seorang $a>$ qid gila.

Jumhur ulama berpendapat bahwa gila membatalkan $m u d\} a>r a b a h$ sebab gila atau sejenisnya membatalkan keahlian dalam $m u d\} a>r a b a h$.

e. Pemilik modal murtad

Apabila pemilik modal murtad (keluar dari Islam) atau terbunuh dalam keadaan murtad, atau bergabung dengan musuh serta telah diputuskan oleh hakim, menurut Imam Abu Hanifah, hal itu membatalkan mud \} $>$ rabah sebab bergabung dengan musuh sama saja dengan mati. Hal itu menghilangkan keahlian dalam kepemilikan harta, dengan dalil bahwa harta orang murtad dibagikan di antara para ahli warisnya. ${ }^{20}$

\section{F. Tinjauan Fiqh Muamalah Terhadap Akad Pada Bank Sampah Srikandi}

Praktek Bank sampah pada dasarnya tidak dibahas secara rinci dalam Islam, tidak ada dalil Al-Qur'an dan hadi>th yang menyebutkan hukum dari praktek Bank Sampah. Masalah hukum boleh atau tidaknya sebenarnya hukum setiap kegiatan muamalah adalah boleh, sesuai dengan kaidah fiqh yang berbunyi:

$$
\text { الأصل فى الأشياء الاباحه حتى يدل الاليل على تحريمه }
$$

Artinya: "Hukum dari segala sesuatu adalah boleh sehingga ada dalil yang mengharamkannya." 21

Berdasarkan kaidah fiqh di atas, sebenarnya hukum praktek Bank Sampah pada umumnya tidak ada masalah, karena sejauh ini belum ada dalil yang mengharamkannya. Akan tetapi, dalam transaksi muamalah ada ketentuan rukun dan syarat yang harus dipenuhi yang berpengaruh dengan sah atau tidaknya suatu transaksi. Hukum boleh tidaknya praktek Bank Sampah mengacu pada kemanfaatan dari praktek pengelolaan Bank Sampah tersebut. Adapun kemanfaatan dari praktek Bank Sampah adalah timbulnya kesadaran masyarakat dalam mengelola sampah karena dengan adanya Bank Sampah ini maka masyarakat yang menjadi nasabah dari bank sampah tidak membuang sampahnya sembarangan dan ini akan

\footnotetext{
${ }^{19}$ Mardani, Fiqh Ekonomi Islam: Fiqh Muamalah (Jakarta: Kencana, 2013), 204.

${ }^{20}$ Ibid.

${ }^{21}$ Jalaluddin Abdurahman al-Suyuti, Al-Ashbāh Wa'al-Nadāir (Beirut: Das al-Fikr, 1996), 82.
} 
berdampak positif terhadap kebersihan dan kenyamanan lingkungan hidup. Selain itu nasabah juga mendapatkan pendapatan dari sampah yang ditabung tersebut.

Islam sendiri melihat paradigma tersebut adalah sebagai hal yang baik dan diperbolehkan karena Bank Sampah ini jauh dari larangan jual beli seperti yang dijelaskan oleh Labib Mz. dalam bukunya yang berjudul "Etika Bisnis Dalam Islam” bahwa:

"Setiap orang Islam boleh mencari nafkah dengan cara jual beli barang mapun jasa, tetapi cara itu harus dilakukan sesuai hukum Islam, yaitu harus saling rela merelakan, tidak boleh menipu, tidak boleh berbohong, tidak boleh merugikan kepentingan umum, bebas memilih dan riil." 22

Prinsip hukum Islam melarang unsur-unsur transaksi perbankan seperti, perniagaan atas barang yang haram, bunga, perjudian dan spekulasi yang disengaja (maisir), serta ketidakjelasan dan manipulatif (gharar). Bank Sampah keluar dari prinsip ini semua sebagaimana yang telah dijelaskan dalam peraturan menteri nomor 13 tahun 2012 bahwa sistem pendapatan Bank Sampah adalah dengan bagi hasil atau bisa disebut dengan mud $a>$ rabah dan kesepakatan jual beli. Allah Ta'ala berfirman dalam surat al-Baqarah ayat 275:

Artinya: "orang-orang yang memakan riba tidak dapat berdiri melainkan seperti berdirinya orang yang kemasukan setan karena gila. Yang demikian itu karena mereka berkata bahwa jual beli itu sama dengan riba. Padahal Alloh telah menghalalkan jual beli dan mengharamkan riba. Barang siapa mendapat peringatan dari Tuhannya, lalu dia berhenti, maka apa yang diperolehnya terdahulu menjadi miliknya dan urusannya kepada Alloh. Barang siapa mengulangi, maka mereka itu penghuni neraka, mereka kekal didalamnya."

Praktek kerjasama di Bank Sampah Srikandi Candimulyo menggunakan sistem bagi hasil yang perjanjiannya dilaksanakan ketika warga mendaftar sebagai nasabah baru di bank sampah. Perjanjian tersebut dilakukan secara lisan tanpa ada tulisan di atas kertas. Tabungan warga yang berupa sampah tersebut akan dikelola oleh pengurus Bank Sampah dan bisa diambil pada awal bulan Ramad\}a>n. Namun pengelola Bank Sampah juga mengijinkan nasabah yang ingin mengambil tabungannya sewaktu-waktu bila nasabah memerlukan.

\footnotetext{
${ }^{22}$ Labib Mz, Etika Bisnis Dalam Islam, (Surabaya: Bintang Usaha Jaya,2006), 15-16.
} 
Jadi analisis kesesuaian sistem praktek Bank Sampah Srikandi ditinjau dari perspektif Fiqh Muamalah yaitu:

1. Rukun dalam akad mud\}a>rbah adalah

a. Pelaku (pemilik modal maupun pelaksana modal)

- $\quad S\} a>h\} i b$ al $M a>l$ dan $m u d\} a>r i b$ nasabah dan Bank sampah srikandi

- Cakap hukum, rela, dan tidak terpaksa

b. Obyek mud\}a>rabah (modal dan kerja)

- Modal berupa sampah nasabah

- Pekerjaan Bank sampah memilah kembali sampah nasabah lalu menjualnya kembali

c. Persetujuan kedua belah pihak ( $i j a>b$ dan $q a b u>l$ )

- Dalam bersepakat menggunakan lisan

d. Nisba $>h$ atau keuntungan

- Nisbah bagi hasil ditentukan pada saat mendaftar menjadi nasabah Bank Sampah.

Mud) $a>$ rabah yaitu suatu produk financial yang berbasis kemitraan (partnership). Dari definisi tersebut diketahui bahwa dalam mud\}a $>$ rabah terdapat dua pihak atau lebih yang berjanji melakukan kerjasama dalam satu kemitraan. ${ }^{23}$ Pihak yang satu adalah pihak yang menyediakan dana sedangkan pihak yang kedua adalah pihak yang menyediakan pikiran, tenaga, dan waktu dengan tujuan untuk mendapatkan keuntungan. Prinsip akad mud\}a $>$ rabah adalah berdasarkan pada sistem bagi hasil, sehingga jika dalam usaha yang disepakati tersebut nantinya akan mengalami keuntungan maka akan dibagi menurut besaran yang telah disepakati kedua belah pihak. Jika terjadi kerugian, maka kerugian akan ditanggung sepenuhnya oleh pemilik modal asalkan kerugian tersebut bukan karena kelalaian dari pengelola sampah.

Shari>at Islam memberikan kebebasan dan kemudahan dalam bermuamalah terutama dalam perjanjian kerjasama. Bebas di sini dalam arti tidak bertentangan dengan ketentuan hukum yang telah ditetapkan dan tidak saling merugikan di salah satu pihak. Gambaran dari pelaksanaan akad dalam praktik kerjasama antara Bank Sampah Srikandi dengan masyarakat ini, menurut penulis belum sesuai dengan akad bagi hasil mud\}a $>$ rabah karena masih adanya kesamaran dalam akad perjanjian mengenai pembagian keuntungan antara dua belah pihak, yaitu akad perjanjian kerjasama tidak tertulis dan tanpa saksi,

\footnotetext{
${ }^{23}$ Sultan Remy Sjahdeini, Perbankan Syari'ah (Jakarta: Kencana, 2014), 2
} 
akibatnya membuka peluang terjadinya penyimpangan seperti: pengelola Bank Sampah berpotensi tidak amanah dalam pembagian hasil. Jadi idealnya perjanjian kerjasama dalam Islam yaitu prosedur perjanjian hendaknya dilakukan secara tertulis. Azhar Basyir mengatakan bahwa perjanjian kerjasama dalam Islam seharusnya memenuhi 3 hal $^{24}$, yaitu:

1. Prosedur perjanjian hendaknya dilakukan tertulis

2. Transparansi dalam pembagian hasil

3. Kerjasama harus didasarkan adanya manfaat dalam menghindari diri dari timbulnya kemadharatan dalam kehidupan masyarakat.

Adanya syarat-syarat yang disebutkan diatas maka dalam muamalah perlu upayaupaya agar pelaksanaan prosedur perjanjian kerjasama antara nasabah dengan pengelola Bank Sampah tidak bertentangan dengan ketentuan-ketentuan yang ditetapkan. Mengenai pelaksanaan system perjanjian kerjasama antara nasabah dan pengelola Bank Sampah yang dilakukan secara lisan atau tidak tertulis ini juga bertentangan dengan firman Allah :

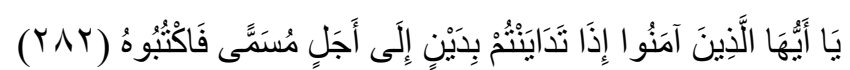

Artinya : "Hai orang-orang yang beriman apabila kamu bermuamalah tidak secara tunai dalam waktu yang ditentukan, maka hendaklah kamu menulisnya. ${ }^{25}$

Berdasarkan ayat di atas, Allah SWT memerintahkan kepada orang-orang yang beriman agar melaksanakan ketentuan-ketentuan yang telah ditetapkan oleh Allah SWT. Apabila mengadakan prosedur perjanjian yang secara tidak tunai supaya melengkapi dengan alat bukti, sebagai dasar untuk menyelesaikan persengketaan yang kemungkinan terjadi dikemudian hari.

Islam membenarkan adanya kerjasama dan memerintahkan agar saling tolong menolong dan tidak merugikan antar sesama manusia sesuai dengan azas muamalat yaitu azas taba'dulu al-mana $>f i$ ' bahwa segala bentuk kegiatan muamalah harus memberikan keuntungan bersama bagi pihak-pihak yang terlibat. Azas ini kelanjutan dari prinsip atta'a>manu atau al-mu'a>wanah. Sehingga azas ini bertujuan menciptakan kerjasama antar individu atau pihak-pihak dalam masyarakat dalam rangka saling memenuhi keperluan masing-masing untuk kesejahteraan bersama. ${ }^{26}$

\footnotetext{
${ }^{24}$ Ahmad Azhar Basyir, Azas-azas Hukum Muamalah (Hukum Perdata Islam),(Yogjakarta UII,1990),57

${ }^{25} \mathrm{Al}$ qur'an dan terjemahnya, (bandung : syamil qur'an, 2012), 282.

${ }^{26}$ Juhaya S. Praja, Filsafat Hukum Islam, ( Bandung: LPPM,1995), 113.
} 
Penggunaan sistem bagi hasi berdasarkan shari>'ah diharapkan mampu menanggulangi permasalahan modal dan peluang usaha yang terjadi selama ini, karena akan menyuburkan kemampuan wirausaha dikalangan anggota masyarakat yang lemah dari sisi permodalan, sehingga usaha kecil dan mikro mampu menyumbang kepada output, lapangan pekerjaan dan distribusi pendapatan. ${ }^{27}$

Jadi setelah mengadakan penelitian melalui dokumentasi dan wawancara penulis berpendapat bahwa pelaksanaan akad antara nasabah dengan pengelola Bank Sampah masih menimbulkan kesamaran. Karena dalam praktek kerjasamanya tidak tertulis, sehingga belum sesuai dengan shariat Islam.

Untuk meraih kemaslahatn bersama, dalam melakukan kerjasama hendaklah dilaksanakan dengan perjanjian tertulis dengan menghadirkan saksi. Apa saja yang menjadi kewenangan kedua belah pihak serta pembagian hasilnya harus jelas dan disebutkan dalam perjanjian. Pihak-pihak yang melakukan pejanjian hendaklah memiliki sifat amanah, menepati janji, mentaati hasil kesepakatan dan menghormati apa yang menjadi hak orang lain.

\section{G. Tinjauan Fiqh Muamalah Terhadap Bagi Hasil Bank Sampah Srikandi di Desa Candimulyo Kec. Dolopo Kab Madiun}

Di dalam ekonomi Islam bagi hasil merupakan salah satu identitas yang tidak bisa dipisahkan. Bagi hasil dalam ekonomi Islam ada berbagai macam salah satunya yaitu

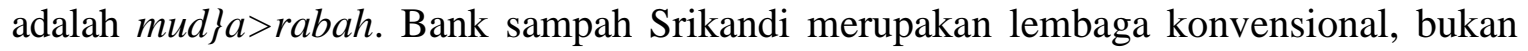
dibentuk sebagai lembaga Syariah, tetapi menggunakan prinsip syariah dalam produknya.

Berdasarkan pasal 6 butir 13 UU No. 10 tahun 1998 tentang Perbankkan, bahwa prinsip bagi hasil adalah aturan perjanjian berdasarkan hukum Islam antara Bank dan pihak lain untuk penyimpanan dana dan pembiayaan kegiatan usaha atau kegiatan lainnya yang dinyatakan sesuai dengan syariah.

Menurut bahasa, bagi hasil adalah transaksi pengolahan bumi dengan (upah) sebagian hasil yang keluar dari padanya ${ }^{28}$. Yang dimaksud di sini adalah pemberian hasil untuk orang mengolah atau menanami tanah atau jenis lainnya dalam hal ini sampah pada Bank sampah dari yang dihasikannya, seperti setengah atau sepertiga atau lebih dari itu atau pula lebih rendah sesuai dengan kesepakatan kedua belah pihak.

${ }^{27}$ Merza Gamal, Aktivitas Ekonomi Syariah, ( Pekanbaru; UNRI Press, 2004), 108.

${ }^{28}$ Muhammad Syafi'i Antonio, Bank Syari'ah dari Teori ke Praktik, (Jakarta: Gema Insani Press,2001), 
Dalam sistem bagi hasil terdapat prinsip-prinsip untuk menjalankan aktivitasnya, yaitu

1. Prinsip keadilan dan kehati-hatian. Ini tercermin dari penerapan imbalan atas dasar bagi hasil dan pengambilan nisbah yang disepakati bersama antara pihak pengelola dengan nasabah kemudian pihak pengelola akan mengembangkan dana yang terkumpul dari nasabah untuk usaha-usaha yang baik secara professional.

2. Prinsip kesederajatan, dimana menempatkan nasabah penyimpan dana pada kedudukan yang sama dan sederajat.

3. Prinsip ketentraman. Yaitu bahwa produk-produk dari Bank telah sesuai dengan prinsip dan kaidah muamalah Islam, antara lain tidak adanya unsur riba. Dengan demikian nasabah akan merasakan ketentraman lahir maupun batin. ${ }^{29}$

Hal-hal yang berkaitan dengan bagi hasil yaitu:

1. Prosentase. Nisbah keuntungan harus didasarkan dalam bentuk prosentase antara kedua belah pihak, bukan dinyatakan dalam nilai nominal rupiah tertentu. Dan nisbah ini ditentukan berdasarkan kesepakatan bukan berdasarkan porsi setoran modal.

2. Bagi Untung dan Bagi Rugi. Dalam kontrak ini, return dan timing cash flow kita tergantung kepada kinerja riilnya.Bila lab bisnisnya besar kedua belah pihak mendapat bagian yang besar pula. Bila laba bisnisnya kecil, mereka mendapat bagian yang kecil pula. Filosofi ini hanya dapat berjalan jika nisbah laba ditentukan dalam bentuk prosentase, bukan dalam bentuk nominal rupiah tertentu.

3. Jaminan. Ketentuan pembagian kerugian yang terjadi hanya murni diakibatkan oleh resiko bisnis bukan karena resiko karakter buruk $m u d\} a>r i b$. Bila kerugian terjadi karena karakter buruk, misalnya karena $m u d\} a>$ rib lalai atau melanggar persyaratanpersyaratan kontrak, maka $S\} a>h\} i b$ al $M a>l$ tidak perlu menanggung kerugian seperti itu.

4. Menentukan besarnya nisbah

Besarnya nisbah ditentukan berdasarkan kesepakatan masing-masing pihak yang berkontrak. Jadi angka besaran nisbah ini muncul sebagai hasil tawar-menawar antara S\}a>hlib al Ma>l dengan mud\}a>rib. Dengan demikian angka nisbah ini bervariasi

${ }^{29}$ Raihanah Daulay, Pengaruh kualitas Pelayanan dan Bagi hasil terhadap Keputusan Menabung Nasabah pada Bank Mandiri Syari'ah di Kota Medan, Jurnal Manajemen dan Bisnis Vol 10 No.01 APRIL 2010 
bisa 50;50, 60:40, 70:30 bahkan 99:1. Namun para ahli fiqh sepakat bahwa nisbah 100:0 tidak diperbolehkan. ${ }^{30}$

Dalam praktek kerjasama antara masyarakat dan Bank sampah Srikandi ini tampak seperti jual beli, dimana masyarakat atau nasabah menjual sampah yang dikumpulkannya kepada Bank Sampah yang membeli sesuai dengan jenis dan beratnya. Uang dari penjualan sampah beserta keuntungan dari nasabah itu kemudian disimpan dalam Bank Sampah dan dikelola dalam bentuk simpan pinjam untuk menyediakan dana atau modal bagi nasabah yang memerlukan. Uang simpanan tersebut diambil setiap setahun sekali ketika awal bulan Ramadhan. Ini diharapkan uang tersebut bisa dimanfaatkan semaksimal mungkin bagi nasabah Bank sampah. Namun tidak menutup kemungkinan nasabah mengambil uang simpanannya sewaktu-waktu ketika membutuhkan dan hal seperti ini juga diperbolehkan dari pihak Bank Sampah.

Di awal pendaftaran sebagai nasabah Bank Sampah Srikandi ini ada semacam perjanjian kerjasama pembagian keuntungan antara nasabah dengan pihak pengelola Bank Sampah. Akad ini sudah ditetapkan di awal perjanjian kerjasama antara Bank sampah dengan masyarakat ketika masyarakat mendaftar sebagai nasabah baru. Prosentase atau dalam akad mud ; $a>$ rabah biasa disebut nisbah dalam bagi hasil di Bank Sampah Srikandi ini adalah 65\%:35\%. Namun nisbah ini bisa berubah ketika harga jual sampah menurun atau ketika stok sampah menumpuk, juga karena hasil kerajinan daur ulang sampah yang kurang diminati oleh warga karena harganya terlalu tinggi jika dibanding dengan kerajinan yang bukan dari hasil daur ulang. Perubahan atau pengurangan dari prosentase pembagian keuntungan ini tanpa ada pemberitahuan kepada pihak nasabah.

Mekanisme bagi hasil dan kerjasama di dalam tabungan sampah, nasabah yang bertindak sebagai $S\} a>h\}$ ib al $M a>l$ menabungkan sampah-sampah mereka pada Bank Sampah Srikandi yang bertindak sebagai mud $\{a>r i b$. Sampah di sini disamakan dengan modal atau harta nasabah. Pihak $S\} a>h\} i b$ al $M a>l$ memasrahkan sampah mereka kepada mud $\} a>r i b$ (tanpa memberi batasan) untuk nantinya sampah tersebut diubah menjadi uang. Karena mud\}a>rib menurut $S\} a>h\} i b$ al $M a>l$ memiliki kemampuan untuk menjual kepada pengepul.

Kemudian setelah sampah tersebut menjadi uang kemudian uang tersebut ditabung dan nanti akan dibagikan setiap awal Ramadhan beserta pembagian hasil atau keuntungan

${ }^{30}$ Adiwarman A Karim, Bank Islam:Analisis Fiqh dan Keuangan, (Jakarta:Raja Grafindo Persada, 2013), 206. 
dari pengelola sampah. Pengambilan tabungan ini juga bisa dilakukan sewaktu-waktu apabila nasabah membutuhkan.

Jadi, dari uraian di atas penulis menyimpulkan bahwa sistem bagi hasil yang di lakukan oleh bank sampah srikandi tidak melanggar atau sesuai fiqh muamalah, karena sudah memenui syarat-syarat yang ada dalam system bagi hasil. Yaitu adanya pembagian nisbah di awal akad perjanjian. Sedangkan perubahan pembagian hasil ketika terjadi penurunan harga sampah dan lain-lain saya kira ini bukan kesalahan dari pengelola Bank Sampah, sehingga nasabah sebagai $S\} a>h\} i b$ al $M a>l$ juga menanggung hasil dari uraian tersebut. Jadi selama perjanjian kerjasama ini dilakukan dengan saling rela dan tidak ada pihak yang mersaa dirugikan, maka sistem bagi hasil ini sah.

\section{Kesimpulan}

Shari>at Islam memberikan kebebasan dan kemudahan dalam bermuamalah terutama dalam perjanjian kerjasama. Bebas disini dalam arti tidak bertentangan dengan ketentuan hukum yang telah ditetapkan dan tidak saling merugikan disalah satu pihak. Gambaran dari pelaksanaan akad dalam praktik kerjasama antara Bank Sampah Srikandi dengan masyarakat ini, menurut penulis belum sesuai dengan akad bagi hasil mud\}a>rabah karena masih adanya kesamaran dalam akad perjanjian mengenai pembagian keuntungan antara dua belah pihak, yaitu akad perjanjian kerjasama tidak tertulis dan tanpa saksi, akibatnya membuka peluang terjadinya penyimpangan seperti: pengelola Bank Sampah berpotensi tidak amanah dalam pembagian hasil. Jadi idealnya perjanjian kerjasama dalam Islam yaitu prosedur perjanjian hendaknya dilakukan secara tertulis.

Bahwa sistem bagi hasil yang dilakukan oleh Bank Sampah srikandi tidak melanggar atau sesuai fiqh muamalah, karena sudah memenui syarat-syarat yang ada dalam sistem bagi hasil. Yaitu adanya pembagian nisbah diawal akad perjanjian, sedangkan perubahan pembagian hasil ketika terjadi penurunan harga sampah dan lain-lain saya kira ini bukan kesalahan dari pengelola bank sampah, sehingga nasabah sebagai $S\} a>h\} i b$ al $M a>l$ juga menanggung hasil dari kerugian tersebut. Jadi selama perjanjian ini dilakukan dengan saling rela dan tidak ada pihak yang merasa dirugikan, maka sstem bagi hasil ini sah. 


\section{DAFTAR PUSTAKA}

Al-Qur'an Terjemah. Surabaya: Karya Agung, 2014.

Anshori, Abdul Ghofur. Hukum Perjanjian Islam di Indonesia. Yogyakarta: Gadjah Mada University Press, 2010.

Antonio, Muhammad Syafie ${ }^{\circ}$. Bank Syariah: Dari Teori ke Praktik. Jakarta: Gema Insani Press, 2001.

Bambang Rustanto. "Bank Sampah” dalam http://bambang rustanto.blogspot.com /2013/08/banksampah.html/ (di akses pada tanggal7september 2018, pukul22.51).

Basyir, Ahmad Azhar. Asas-AsasHukum Mu'Amalat. Yogyakarta: UII Pres, 2000.

Dahlan, Ahmad. Bank Syariah: TeoritikpraktikKritik. Yogyakarta: Teras, 2012.

Damanuri, Aji.Metodologi Penelitian Mu'amalah. Ponorogo: STAIN Ponorogo Press, 2010.

Daulay, Raihanah. Pengaruh kualitas Pelayanan dan Bagi hasil terhadap Keputusan

Menabung Nasabah pada Bank Mandiri Syari’ah di Kota Medan, Jurnal Manajemen dan Bisnis Vol 10 No.01 APRIL 2010

Departemen Agama RI. Al-Qur'an dan Terjemahnya. Bandung: Sha>mil Qur"an, 2012.

Gamal, Merza. Aktivitas Ekonomi Syariah, Pekanbaru; UNRI Press, 2004

Hadi, Sutrisno. Metode Research. Yojakarta: Andi Offset, 2002.

Hesti. Wawancara sebagai bendahara Bank Sampah Srikandi, 18 Desember 2018

Ibnu Majah, Al-Hafidz Abi Abdillah Muhammad bin Yazid al- Qazwiniy. Sunan Ibnu Majah Juz 3. Beirut: Dar al-Fikr, 1992.

Karim, Adiwarman A. Bank Islam:Analisis Fiqh dan Keuangan, Jakarta:Raja Grafindo Persada, 2013.

Mahkamah Agung Republik Indonesia.Kompilasi Hukum Ekonomi Syari'ah (KHES). 2008.

Manan, M. Abdul. Islamic Economics Theory and Practice, Terj. Nastangin " Teori dan Praktek Ekonomi Islam”. Yogjakarta: PT. Dana Bhakti Wakaf, 1997. Mardani. "Fiqh Ekonomi Islam: Fiqh Muamalah (Jakarta: Kencana, 2013).

Mohammad Elmeidian. "Perspektive Islam Dalam Management SampahAtau Limbah." dalam http://fo-kalink.blogspot.com/2011/06/perspektive-islam dalammanagement.html/(di akses pada tangga 17 September 2018 pukul 22.57).

Mz, Labib.EtikaBisnisDalam Islam. Surabaya: Bintang Usaha Jaya, 2006.

Naf'an. PembiayaanMusha>rakah dan Mud \}a>rabah. Yogyakarta: Graha Ilmu, 2014. Naja, Daeng. Akad Bank Syariah. Yogyakarta: Pustaka Yustisia, 2011. 